\title{
ANALISIS PERAN GURU IPS DALAM MENUMBUHKAN SIKAP SOSIAL SISWA DI SMPI AS-SHOFIANI AHMADI
}

\author{
Ainun Habibah ${ }^{1(*)}$, Eka Putri ${ }^{2}$ \\ Universitas Panca Sakti, Bekasi, Indonesia ${ }^{12}$ \\ ainunhabibah24@gmail.com ${ }^{1}$, ekaputri.15juni92@gmail.com²
}

\begin{abstract}
Received: 11 Agustus 2021 Nilai-nilai pancasila tampaknya tidak tercermin pada anak muda, Revised: 11 Agustus 2021 terbuyarkan oleh perubahan zaman yang semakin berkembang saat ini. Accepted: 20 Agustus 2021 Meskipun demikian, dalam persepsi yang mendasarinya, ditemukan juga masalah-masalah yang berkaitan dengan perilaku siswa, lebih spesifiknya masih ada beberapa siswa yang membutuhkan kebiasaan, yang perlu diperhatikan dan sopan kepada ahli, seperti tidak adanya kabar baik dan salam hangat dari ahli. Melalui tugas ahli mata pelajaran IPS dengan membingkai karakter sosial pada siswa, diyakini bahwa mereka akan benar-benar ingin mengubah perilaku siswa tersebut. Penelitian ini bertujuan untuk mengidentifikasi dan menganalisis peran guru IPS, sikap sosial siswa, pengaruh peran guru dalam menumbuhkan sikap sosial siswa, dan faktor yang mempengaruhi rendahnya sikap sosial siswa. Penelitian ini menggunakan metode survei dan di deskripsikan secara kuantitatif. populasi sebesar 85 siswa didapati sample 85 siswa dengan menggunakan teknik total sampling. Berdasarkan penelitian ini, dapat disimpulkan bahwa terdap pengaruh yang signifikan antara peran guru IPS dalam menumbuhkan sikap sosial siswa.
\end{abstract}

Keywords: Peran guru, IPS, Sikap sosial

(*) Corresponding Author: Habibah, ainunhabibah24@gmail.com

How to Cite: Habibah, A. \& Putri, E. (2021). Analisis Peran Guru Ips Dalam Menumbuhkan Sikap Sosial Siswa Di SMPI As-Shofiani Ahmadi. Research and Development Journal of Education, 7 (2), 343-352.

\section{INTRODUCTION}

Pendidikan sangat penting bagi kemajuan bangsa Indonesia (SDM) dalam Pendidikan merupakan hal penting demi kemajuan SDM (Sumber Daya Manusia) Indonesia dalam menghadapi era globalisasi. Melalui pendidikan ini manusia dibentuk agar memiliki pengetahuan, hidup mandiri, dan berakhlak atau berkarakter. Tujuan pendidikan yang terdapat dalam batang tubuh pembukaan undang-undang dasar 1945 alinea ke empat yaitu "mencerdaskan kehidupan bangsa".

Kemudian diperinci dan diperjelas dalam Undang Undang No. 20 Tahun 2003 pasal 3 menjelaskan bahwa pendidikan nasional berfungsi mengembangkan kemampuan dan membentuk watak serta peradaban bangsa yang bermartabat dalam rangka mencerdaskan kehidupan bangsa. Untuk itu, pendidikan nasional bertujuan untuk mengembangkan potensi peserta didik agar menjadi manusia yang beriman dan bertakwa kepada Tuhan Yang Maha Esa, berakhlak mulia, sehat, berilmu, cakap, kreatif, mandiri, dan menjadi warga negara yang demokratis serta bertanggungjawab (Mulyasa, 2013: 20).

Pendidikan merupakan fondasi bangsa, melalui lembaga pendidikan sumber daya manusia Indonesia akan lebih berkualitas dan bermartabat. Hal ini tidak terlepas dari peran semua komponen dalam lembaga pendidikan. Dimana yang berperan dalam lembaga pendidikan meliputi kepala sekolah, wakil kepala sekolah, staf dan pengurus lembaga sekolah, dan pendidik atau guru. 
Guru merupakan personalia penting dalam pendidikan, selain itu guru merupakan seorang yang hubungannya paling dekat dengan peserta didik. sebagian besar interaksi yang terjadi di sekolah, adalah interakasi guru dengan peserta didik. Baik melalui proses pembelajaran akademik kulikuler, ekstrakulikuler. Di sekolah guru merupakan figur yang diharapkan mampu mendidik anak yang berkarakter, berbudaya dan bermoral (Zubaedi, 2013: 164). Pendidikan di sekolah ada di tangan guru, karena guru mempunyai peranan dalam proses pertumbuhan dan perkembangan siswanya self concept, pengetahuan, keterampilan, kecerdasan, dan sikap serta pandangan hidup siswa (Mujtahidin, 2011: 34).

Tugas seorang guru tidak hanya di sekolah akan tetapi di lingkungan masyarakat ia juga harus menjadi panutan masyarakat. Guru harus menjadi seorang dewasa yang berbeda dengan orang dewasa lainnya. Artinya ia harus senantiasa berperilaku yang baik di lingkungan sekolah dan di lingkungan masyarakat, karena segala tindakannya senantiasa akan ditiru oleh siswa. Peranan guru di sekolah ditentukan oleh kedudukannya sebagai orang dewasa, sebagai pengajar dan pendidik dan sebagai pegawai, yang paling utama ialah kedudukannya sebagai pengajar dan pendidik, yakni sebagai guru.

Berdasarkan kedudukannya sebagai seorang guru harus menunjukan kelakuan yang layak bagi guru menurut harapan masyarakat, apa yang dituntut dari guru dalam aspek etis, intelektual dan sosial lebih tinggi dari pada yang dituntut dari orang dewasa lainnya. Guru sebagai pendidik dan pembina generasi muda harus menjadi teladan, di dalam maupun di luar sekolah .

Guru memegang peranan yang sangat strategis terutama dalam membentuk karakter serta mengembangkan potensi siswa. Dalam fenomena dekadensi moral remaja yang sedang dihadapi pada era globalisasi, peranan guru menjadi sangat penting dalam proses pendidikan terutama guru IPS. Guru IPS mengemban tugas yang sangat urgen dalam hal ini terutama dalam menumbuhkan karakter, menanamkan nilai-nilai karaktrer sosial kepada peserta didik. Guru IPS mempunyai tugas mulia dan menjadi fondasi penting bagi pengembangan intelektual, emosional, kultural, dan sosial peserta didik, yaitu mampu menumbuhkan cara berfikir, bersikap, dan berprilaku yang bertanggungjawab selaku individu, warga masyarakat, warga negara, dan warga dunia. IPS juga bertugas mengembangkan potensi peserta didik agar peka terhadap masalah sosial yang terjadi di masyarakat, memiliki sikap mental positif untuk perbaikan segala ketimpangan, dan keterampilan mengatasi masalah yang dihadapi dalam kehidupan sehari-hari.

Hakikat IPS dalam pengertian yang terpadu inilah yang diajarkan di tingkat pendidikan dasar dan menengah. Dengan pengertian itu menunjukkan bahwa IPS sebenarnya merupakan pelajaran yang cukup komprehensif yang dapat menjadi salah satu instrument untuk ikut memecahkan masalah-masalah sosio-kebangsaan di Indonesia. Tujuan pembelajaran IPS, secara umum dapat dirumuskan antara lain untuk mengantarkan, membimbing dan mengembangkan potensi peserta didik agar : (1) menjadi warga negara (dan juga warga dunia) yang baik; (2) mengembangkan pemahaman mengenai pengetahuan dasar kemasyarakatan, (3) mengembangkan kemampuan berpikir kritis dengan penuh kearifan dan keterampilan inkuiri untuk dapat memahami, menyikapi, dan mengambil langkah-langkah untuk ikut memecahkan masalah sosial kebangsaan, (4) membangun komitmen terhadap nilai-nilai kemanusiaan dan menghargai serta ikut mengembangkan nilai-nilai luhur dan budaya Indonesia, dan (5) mengembangkan kemampuan berkomunikasi dan bekerja sama dalam kehidupan masyarakat yang majemuk, baik lokal, regional maupun internasional. Memahami uraian tentang pengertian dan tujuan pembelajaran IPS di atas, nampaknya sangat erat kaitannya dengan pendidikan karakter. Pendidikan karakter yang dapat dimaknai sebagai pendidikan nilai, pendidikan moral atau pendidikan budi pekerti (Zuchdi, 2008:5). 
Berdasarkan penjelasan di atas, bahwa pelajaran IPS memiliki urgensi dalam membangun karakter penerus bangsa yang beradab sesuai dengan nilai-nilai luhur bangsa Indonesia yaitu pancasila. IPS adalah mata pelajaran yang bersifat dinamis sehingga dalam era globalisasi ini IPS sangat penting dalam upaya mempelajari kehidupan modern dengan tidak melupakan karakter bangsa. Fenomena globalisasi telah menghantarkan generasi muda kearah krisis moral. Nilai-nilai pancasila seolah tidak tercermin dalam diri kaula muda, terkikis dengan perubahan zaman yang semakin modern (Nasution, 2010:91).

Nilai keberadaban tidak lagi dijunjung tinggi, padahal itu merupakan cerminan dasar bangsa Indonesia. kemerosotan nilai-nilai kebangsaan pada diri generasi muda sebagai dari dampak kemajuan ilmu pengetahuan dan teknologi. Pembelajaran IPS harus dikemas agar menjadi pembelajaran yang aktif, inovatif, kreatif, efektif, dan menyenangkan sehingga nilai-nilai pancasila yang ditanamkan tidak hanya berlangsung di dalam kelas, Akan tetapi akan tertanam secara sukarela dalam diri siswa sehingga siswa dapat mengaplikasikannya secara reflek dalam kehidupan sehari-hari baik di lingkungan sekolah, lingkungan keluarga, dan lingkungan masyarakat (Zubaedi, 2013:287).

Dengan manajemen pembelajaran yang tepat pembelajaran IPS akan lebih optimal dalam membangun karakter peserta didik. Pembentukan karakter sosial siswa menjadi suatu keharusan seorang guru IPS. Sehingga pada diri siswa mempunyai filter sebagai benteng untuk mempertahankan nilai-nilai luhur bangsa Indonesia melalui implementasi pendidikan karakter yang terintegrasi pada pembelajaran IPS.

Karakter sosial kaitannya adalah dengan sikap atau perilaku individu dalam berhubungan dengan individu lain atau masyarakat. Manusia sebagai mahluk sosial tentunya manusia akan berhubungan dengan manusia lainnya. Seseorang yang memiliki karakter sosial yang baik tentunya akan menjalankan kehidupannya sesuai dengan nilai dan norma yang berlaku dalam lingkungan sosial individu tersebut.

Berkaitan dengan pembentukan karakter sosial siswa dapat dilakukan oleh guru IPS, karena dalam mata pelajaran IPS memiliki kajian yang luas tentang kehidupan manusia dengan lingkungannya. Selain itu juga, guru IPS memiliki potensi yang tepat dalam membentuk karakter sosial siswa. Berdasarkan pengamatan awal di lapangan terlihat bahwa guru yang mengajar mata pelajaran IPS adalah tenaga professional yang sesuai dengan lulusan kependidikannya yaitu IPS. Pada pembelajaran IPS guru mengaitkan materi pelajaran IPS dengan pembentukan karakter sosial siswa. Seperti menjelaskan kepada siswa bahwa harus memiliki sikap sopan santun baik terhadap guru atau orang tua, harus disiplin, saling menghargai antar sesama teman, dan jangan malas belajar terutama mengerjakan tugas atau pekerjaan rumah yang diberikan oleh guru IPS.

Namun dalam pengamatan awal juga ditemukan masalah yang berkaitan dengan prilaku siswa yaitu masih ada beberapa siswa yang kurang memiliki sikap budi pekerti, dimana kurang menghargai dan bersikap santun kepada guru seperti kurangnya tegur sapa dan bersalaman dengan guru. Melalui peran guru mata pelajaran IPS dengan membentuk karakter sosial pada diri siswa diharapkan akan mampu merubah sikap siswa tersebut.

Berdasarkan uraian di atas maka penulis tertarik untuk memunculkan dan mengangkat masalah tentang guru IPS memiliki peranan penting dalam membentuk karakter sosial siswa. Hal ini dikarenakan kajian ilmu pengetahuan sosial sangat luas yang di dalamnya mencakup nilai-nilai kemanusiaan. 


\section{METHODS}

Penelitian dilakukan di SMPI As-Shofiani Ahmadi yang berlokasi di Kp. Kedung Ringin 003/002, Desa, Sukaringin, Kec, Sukawangi, Kab, Bekasi. Adapun waktu penelitian penulis lakukan mulai tanggal 01 Mei 2021 sampai tanggal 05 Juni 2021 tahun ajaran 2020/2021 semester genap. Kemudian penelitian ini dilakukan dengan menggunakan metode deskriptif dengan pendekatan kuantitatif. Teknik pengumpulan data yang digunakan dalam penelitian ini adalah observasi (dimana penulis melakukan pengamatan langsung secara cermat terhadap objek sasaran yang akan di teliti, yakni mengikuti kegiatan yang dilakukan oleh peserta didik dan pendidik di sekolah), angket (ialah teknik yang dilakukan dengan cara memberi seperangkat pertanyaan atau pernyataan tertulis kepada responden untuk dijawab), dan dokumentasi. Dalam penelitian ini, populasi yang diamati adalah peserta didik SMPI As-Shofiani Ahmadi Tahun Ajaran 2020/2021. Sedangkan sampel yang penulis ambil dengan jumlah populasi 85 peserta didik. Dengan teknik pengambilan sampel yaitu total sampling. Total sampling adalah teknik penentuan sampel bila semua anggota populasi digunakan sebagai sampel. Jadi sampel yang penulis ambil sebanyak 85 peserta didik sesuai populasi. Teknik analisis data menggunakan uji deskriptif dan uji hipotesis.

\section{RESULTS \& DISCUSSION}

\section{Results}

\section{Analisis Deskriptif}

Peran Guru IPS memiliki pengaruh terhadap Sikap Sosial Siswa. Hal ini penulis dibuktikan dari data melalui rumus product moment yang menghasilkan koefisien korelasi sebesar 0,77 yang menunjukkan adanya korelasi antara peran Guru IPS dengan sikap sosial siswa, dan hasil tersebut berada dalam rentang 0,71 - 0,90 yaitu korelasi yang tinggi atau kuat. Jika dilihat dari dari hasil perhitungan dengan menggunakan rumus coefficient of determination (KD), maka diperoleh KD sebesar $59,29 \%$, artinya kontribusi variabel $\mathrm{X}$ terhadap variabel $\mathrm{Y}$ sebesar 59,29\%, sedangkan 40,71\% dipengaruhi oleh faktor lain.

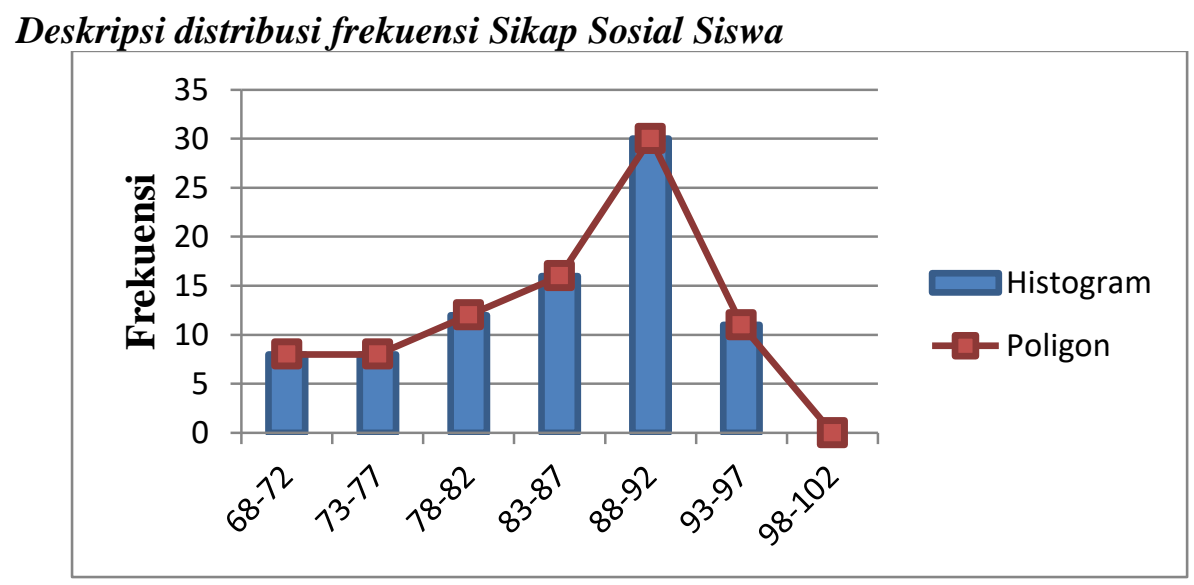

Gambar 1.

Distribusi Frekuensi Sikap Sosial Siswa

Sumber : Peneliti (2021) 


\section{Deskripsi distribusi frekuensi Peran Guru IPS}

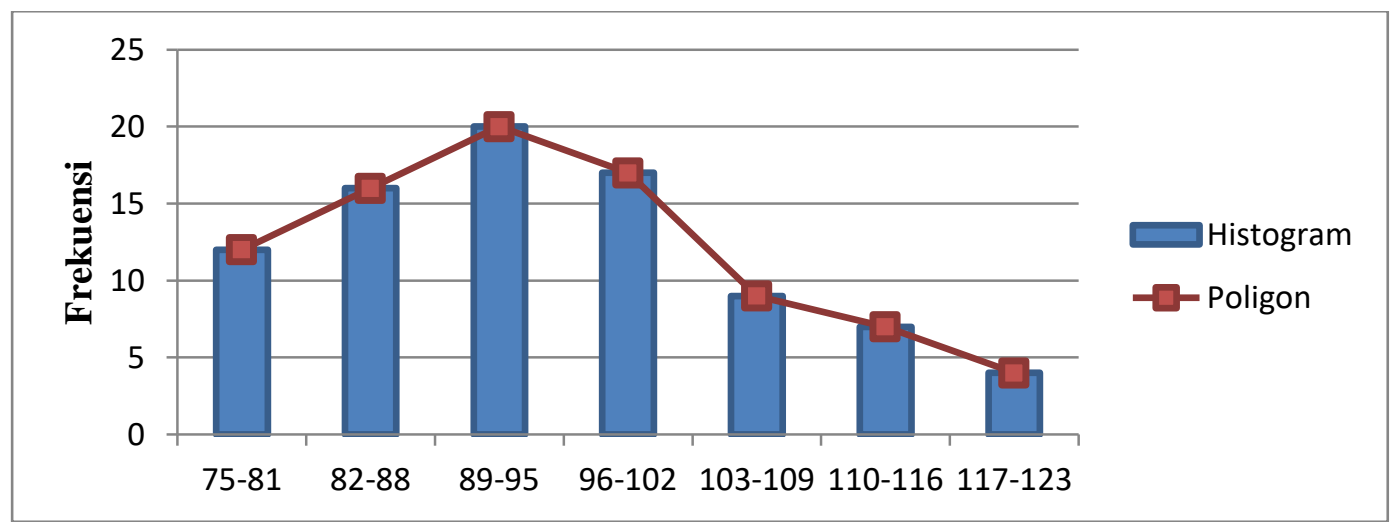

Gambar 2.

Distribusi Frekuensi Peran Guru IPS

Sumber : Peneliti (2021)

\section{Analisis Kuantitatif}

\section{a. Pengujian Persyarat Analisis}

\section{1) Uji Normalitas}

Jenis data yang digunakan untuk pengujian normalitas yaitu uji kolmogrovsmirnov. dengan taraf nyata $\alpha=0,05$, dari daftar nilai kritis $F$ untuk Uji Kolmogorov-Smirnov dengan $n=85$ didapati nilai distribusi $\mathrm{F}_{\text {tabel }}$ sebesar 2,33. Didapatkan $F_{\text {tabel }}=2,33$ yang lebih besar dari $F_{\text {hitung }}=1,11$ sehingga Hipotesis nol $\left(\mathrm{H}_{0}\right)$ diterima maka dianggap sampel tersebut berdistribusi normal. $a_{\max }=0,0717 \mathrm{D}_{\text {tabel }}=0,145$ Karena $a_{\max }<D_{\text {tabel, }}$ maka data distribusi normal.

\section{2) Uji Homogenitas}

Hasil analisis menjukkan bahwa Karena $F_{\text {hitung }}(1,11)<F_{\text {tabel }}(2,33)$, maka $\mathrm{H}_{0}$ diterima. Artinya kedua kelompok data tersebut memiliki variansi homogenya.

\section{3) Uji Kelinearan Regresi}

ANOVA untuk Regresi Linier $\widehat{Y}=38,5155+0,4902 X$

\begin{tabular}{|l|c|c|c|c|c|}
\hline \multicolumn{1}{|c|}{ Sumber Variansi } & Dk & JK & RJK & Fh & Ft \\
\hline Total Jk (T) & 85 & 617472 & - & & \\
\cline { 1 - 5 } Regresi (a) & 1 & 612595,9529 & 612595,9529 & & \\
Regresi (b/a) & 1 & 2883,1112 & 2883,111247 & \multirow{2}{*}{1,11} & \multirow{2}{*}{2,33} \\
Sisa (S) & 83 & 1992,9358 & 24,0113 & & \\
\cline { 1 - 3 } Tuna Cocok (TC) (K-2) & 37 & $-188172,8995$ & $-5085,75404$ & & \\
Galat (G) (n-K) & 46 & 190165,8353 & 4134,0399 & & \\
\hline \multicolumn{5}{c}{ Gambar 3. } \\
Linearitas dan Regresi Linear \\
\multicolumn{6}{c}{ Sumber : Peneliti (2020) }
\end{tabular}


Untuk menentukan koefisien regresi maka didapat nilai $\mathrm{a}=38,5154$ dan nilai $\mathrm{b}=0,4902$ dengan demikian persamaan regresi linear adalah $38,5155+$ $0,4902 X$. Karena $F_{\text {hitung }}(1,11)<\mathrm{F}_{\text {tabel }}(2,33)$, maka regresi berpola linear

\section{Uji Hipotesis}

Dari hasil penghitungan diatas, dapat diketahui bahwa angka antara variabel $\mathrm{X}$ dan variabel $\mathrm{Y}$ terdapat korelasi yang tinggi atau kuat. Dengan memperhatikan besarnya $\mathrm{R}_{\mathrm{XY}}(0,77)$ yang terletak di antara $0,71-0,90$ Kemudian untuk mengetahui derajat kebebasan atau df (degree of freedom) didapati yakni Df (83). Selanjutnya, untuk mengetahui apabila Hipotesis penelitian ini terdapat pengaruh yang tinggi atau kuat, maka perlu dibuktikan dengan menguji t Berdasarkan uji t didapati nilai $\mathrm{t}_{\text {hitung }}$ sebesar 17,23 dan $t_{\text {tabel }}$ sebesar 1,99 dengan tarap nyata 0,05 Df 83, maka ada pengaruh yang signifikan Artinya Hipotesis Nol $\left(\mathrm{H}_{0}\right)$ ditolak dan Hipotesis Alternatif $\left(\mathrm{H}_{\mathrm{a}}\right)$ diterima. Dan untuk mengetahui seberapa besar kontribusi yang diberikan variabel $\mathrm{X}$ terhadap Variabel $\mathrm{Y}$, maka harus diketahui melalui coefficient of determination (korelasi penentu) Berdasarkan uji KD didapati nilai sebesar 59,29\%, artinya kontribusi Variabel $\mathrm{X}$ terhadap variabel $\mathrm{Y}$ sebesar 59,29\%, sedangkan $40,71 \%$ dipengaruhi oleh faktor lain.

\section{Discussion}

Guru adalah orang yang berperan dalam proses pembelajaran untuk memberikan ilmu pengetahuan kepada peserta didik. Maksud dari kata Guru yakni Guru seseorang yang mengajarkan, memberi arah, membimbing serta mengawasi siswa selama di lingkungan sekolah.

Menurut Purwanto (2014), istilah "guru" sekarang sudah mendapat arti yang luas lagi dalam masyarakat. Semua orang yang pernah memberikan suatu ilmu atau kepandaian tertentu kepada seseorang atau kelompok orang dapat disebut "guru", misalnya guru silat, guru mengetik, guru menjahit, dll. Menjadi seorang Guru tidak hanya mengajrakan dikelas saja namun, diharuskan juga menanamkan sikap sosial kepada setiap siswa ketika pembelajaran, Guru tidak hanya memberikan ilmu pengetahuan saja, melainkan memberikan contoh ataupun mengarahkan pentingnya sikap sosial bagi setiap individu.

Hasil penelitian ini menemukan bahwa peran guru dalam menumbuhkan sikap sosial siswa sangat berpengaruh. Wardani (2010) mencirikan gagasan pekerjaan instruktur sebagai upaya. misalnya, mengajar, mendidik, mengarahkan, mengkoordinasikan, dan menilai apa yang umumnya diharapkan untuk diselesaikan oleh seorang pendidik sebagai jenis keistimewaan dan komitmennya untuk kesejahteraan ekonomi. diberikan kepadanya oleh masyarakat. Peran guru pada pendidikan karakter ditambah dengan usaha membiasakan perilaku pada peserta didik agar karakter yang disampaikan dapat tertanam dengan kuat pada diri peserta didik.

Wardani (2010) Menelaah lebih lanjut tugas pengajar, saat ini peran pengajar tidak hanya sebatas tugas mendidik. Selain pengajar yang berperan sebagai pengajar ilmiah, pengajar saat ini juga berlaku sebagai pribadi atau guru yang baik. Adanya tugas instruktur sebagai instruktur pribadi menuntut pendidik untuk melakukan misalnya, model hanya sebagai panduan untuk mengakui perilaku merek yang mencakup pemikiran, hati, dan perasaan pada siswa mereka. Instruktur dan pendidik pergi sebagai model peningkatan karakter dengan menetapkan pilihan mahir tergantung pada pengaturan yang ramah dan baik. Hubungan antara instruktur atau guru dengan murid- 
muridnya harus didasarkan pada pemujaan, kepercayaan bersama, jauh dari diktator dan keadaan memanjakan.

Hamdayana (2016) mengemukakan peran guru dalam proses belajar mengajar yang dianggap paling dominan dan klasifikasi guru sebagai: demonstrator, Ada dua konteks guru sebagai demonstrator menurut Wina Sanjaya. Yakni (1) Guru harus menunjukkan sikap-sikap yang terpuji dalam setiap aspek kehidupan. Apa yang menjadi tingkah laku guru akan menjadi acuan bagi anak. (2) Guru harus dapat menunjukkan bagaimana caranya agar setiap materi pelajaran bisa lebih dipahami dan dihayati oleh setiap anak. Sebagai manajer/pengelola kelas. Menurut Jumanta (2016) bahwa Sebagai supervisor instruktur bertanggung jawab untuk mengikuti iklim kelas yang sebenarnya sehingga secara konsisten menyenangkan untuk belajar dan mengkoordinasikan atau membimbing siklus ilmiah dan sosial di wali kelas. Dengan cara ini, pendidik memberdayakan siswa untuk belajar, tetapi juga menumbuhkan keterampilan kerja dan belajar yang kuat di antara siswa.

Sebagai perantara, pengajar sebagai perantara juga dicirikan sebagai pemasok media pembelajaran. Sebagai fasilitator, menurut Rusman (2014) merekomendasikan bahwa sebagai fasilitator, pendidik harus dapat memberikan fasilitas yang memungkinkan kemudahan latihan pembelajaran bagi siswa. instruktur harus memiliki pilihan untuk mencari aset pembelajaran yang berharga dan dapat mendukung pencapaian tujuan dan ukuran pendidikan dan pembelajaran, terlepas dari apakah sebagai orang aset, bacaan kursus, majalah atau makalah dan sebagai evaluator, pendidik tidak hanya menyelesaikan adaptasi tetapi juga memimpin penilaian atau penilaian siswa. bagaimana hal itu dicapai selama siklus belajar.

Hasil penelitian ini kembali menunjukkan bahwa ada beberapa faktor yang dapat menahan mentalitas sosial siswa, yaitu faktor dalam dan faktor luar tertentu. Temuan ini dikuatkan oleh Azwar (1995) bahwa ada 2 faktor yang menghambat perkembangan perspektif sosial siswa, khususnya aspek hereditas (keturunan) dan aspek sosial. Keturunan adalah keseluruhan atribut individu yang diperoleh dari wali kepada anakanak, atau semua potensi (baik fisik maupun mental) yang dimiliki orang sejak saat asalnya sebagai warisan dari wali melalui kualitas. Ada beberapa komponen ekologi, khususnya seperti;

1) Keluarga

Alasan pentingnya peran keluarga untuk kemajuan anak-anak adalah bahwa keluarga adalah kumpulan utama orang-orang yang menjadi titik fokus dari anak; keluarga adalah iklim utama yang memperkenalkan kualitas kehidupan dengan anak-anak; wali dan kerabat adalah "individu besar" untuk peningkatan karakter anak; keluarga sebagai organisasi yang bekerja dengan kebutuhan dasar (manusia), baik fisik-alam, dan sosial-mental, dan anak-anak menginvestasikan banyak waktu dalam iklim keluarga

2) Sekolah

Sekolah merupakan lembaga pendidikan formal yang secara sistematis melaksanakan program bimbingan, pengajaran, dan/atau pelatihan dalam rangka membantu para siswa agar mampu mengembangkan potensinya secara optimal, baik yang menyangkut aspek moral-spiritual, intelektual, emosional, sosial, maupun fisikmotoriknya. Hurlock mengemukakan bahwa sekolah merupakan faktor penentu bagi perkembangan kepribadian anak, baik dalam cara berpikir, bersikap, maupun berperilaku.

3) Teman sebaya

Melalui kelompok teman sebaya, anak dapat memenuhi kebutuhannya untuk belajar berinteraksi sosial, belajar menyatakan pendapat dan perasaan, belajar merespons 
atau menerima pendapat dan perasaan orang lain, belajar tentang norma-norma kelompok, dan memperoleh pengakuan dan penerimaan sosial.

4) Media masa

Menurut Yusuf dan Sugandhi (2011), salah satu komunikasi luas yang saat ini menjadi perhatian warga, khususnya anak muda, adalah TV. TV memiliki dampak positif dan negatif. Akibat buruknya terlihat dari hasil pemeriksaan tersebut, bahwa anak-anak yang menonton acara TV kasar pada umumnya akan menjadi pemarah. Sementara itu, jika acara yang ditonton anak-anak merupakan acara yang layak, anak-anak pada umumnya akan bertindak prososial.

Maka dari penelitian ini menemukan bahwa guru IPS harus berperan sangat penting dalam menumbuhkan sikap sosial siswa karna banyak faktor-faktor yang menjadi penghambat penumbuhan sikap sosial siswa. Dalam pembelajaran IPS, yang menekankan pada aspek praktik bukan hanya aspek teoritis. Guru pelajaran IPS dengan mudah menumbuhkan sikap sosial siswa ketika pembelajaran karena pembalajaran IPS berdominan dengan penekanan interaksi sosial. Dari situ bisa dilihat bahwa bagaimana tingkat sikap sosial siswa.

Dalam interaksi sosial, orang-orang merespons untuk membentuk contoh-contoh perspektif tertentu terhadap berbagai item mental yang mereka hadapi. Beberapa faktor yang mempengaruhinya, yaitu;

1) Pengalaman individu, apa yang telah dan sedang kita hadapi akan membantu membentuk dan memengaruhi antusiasme kita terhadap dorongan sosial. Untuk memiliki pilihan untuk membentuk premis pengembangan mentalitas, pengalaman individu harus memiliki kesan yang kuat. Dengan cara ini, mentalitas akan lebih mudah dibingkai jika pengalaman individu terjadi dalam keadaan yang mencakup variabel-variabel gairah.

2) Dampak orang lain yang dianggap signifikan. Sebagai aturan umum, orang pada umumnya akan memiliki mentalitas yang tradisionalis atau sesuai dengan perilaku individu yang dianggap signifikan, yang diilhami oleh kerinduan untuk menjauh dari perjuangan dengan individu yang dianggap signifikan. Di masa muda dan keremajaan, wali biasanya menjadi figur utama bagi anak-anak.

3) Dampak budaya, cara hidup tempat kita hidup dan tumbuh mempengaruhi perkembangan cara pandang kita. Kebudayaan telah mewarnai mentalitas individuindividu dari daerah setempat, karena kebudayaan adalah hal yang memberikan pengalaman orang-orang yang merupakan individu-individu dari daerah yang diasuhnya. Hanya karakter individu yang sudah mapan dan kokoh dapat mereduksi kekuatan budaya dalam penataan cara pandang individu.

4) Komunikasi yang luas. Dalam menyampaikan data sebagai tugas pokoknya, komunikasi yang luas menyampaikan pesan-pesan yang berisi gagasan-gagasan yang dapat memandu penilaian seseorang. Pesan-pesan menarik yang disampaikan oleh data, jika cukup, akan memberikan premis perasaan yang penuh dalam menilai sesuatu sehingga terbentuklah mentalitas tertentu.

5) Yayasan instruktif dan organisasi yang ketat. Fondasi instruktif dan organisasi yang ketat sebagai kerangka kerja berdampak pada penataan mentalitas karena mereka meletakkan alasan untuk pemahaman dan ide-ide yang baik pada orang. Pemahaman tentang baik dan buruk, garis pemisah antara apa yang diperbolehkan dan apa yang tidak mungkin diperoleh dari sekolah dan dari fokus dan pelajaran yang ketat.

6) Dampak elemen antusias. Sesuai Azwar (1995), berpendapat bahwa, organisasi instruktif dan fondasi yang ketat sebagai kerangka kerja berdampak pada pengembangan mentalitas karena mereka meletakkan alasan untuk pemahaman dan ide-ide bagus pada orang. Pemahaman tentang baik dan buruk, garis pemisah antara 
apa yang diperbolehkan dan apa yang tidak mungkin diperoleh dari pelatihan dan

dari fokus dan pelajaran yang ketat.

Dapat disimpulkan bahwa ada beberapa faktor yang mempengaruhi kemajuan perspektif sosial mahasiswa, khususnya faktor dalam dan faktor luar. Komponen genetik adalah warisan orang tua dan variabel antusias, sedangkan faktor luar adalah unsur alam, baik keluarga, pertemuan sekolah dan teman, selain dampak individu yang dipandang penting, komunikasi luas, dan budaya.

\section{CONCLUSION}

Sikap sosial siswa menurun dengan adanya pandemi covid-19 ini semua kegiatan dilakukan dirumah sehingga siswa sulit untuk berinterkasi dengan sesama teman, dengan keadaan tersebut membuat sikap sosial siswa menurun. Dan lingkungan keluarga yang tidak begitu baik membuat sikap sosial siswa semakin tidak terpantau guru hanya mampu memantau ketika pembelajaran melalui daring, itupun banyak kendala dan kesulitan namun, dengan semaksimal mungkin guru selalu memantau dan menerapkan sikap sosial siswa karena di kurikulum 2013 ini menekankan kepada Sikap. Karena peran seorang guru bukan hanya mengajar. Namun, menjadi Fasilitator, mediator, evaluator dan menejer.

Guru IPS harus berperan sangat penting dalam menumbuhkan sikap sosial siswa karna banyak faktor-faktor yang menjadi penghambat penumbuhan sikap sosial siswa. Dalam pembelajaran IPS, yang menekankan pada aspek praktik bukan hanya aspek teoritis. Guru pelajaran IPS dengan mudah menumbuhkan sikap sosial siswa ketika pembelajaran karena pembalajaran IPS berdominan dengan penekanan interaksi sosial. Dari situ bisa dilihat bahwa bagaimana tingkat sikap sosial siswa. Ada beberapa faktor yang dapat menahan mentalitas sosial siswa, yaitu faktor dalam dan faktor luar. Faktor dalam bisa dari, hereditas atau keturunan dan faktor luar bisa dari lingkungan keluarga, sekolah, teman sebaya, media masa, lingkungan masyarakat, dan budaya.

\section{REFERENCES}

Azwar, S. (1995). Sikap Manusia: Teori dan Pengukurannya. Yogyakarta: Pustaka Pelajar.

Jumanta, H. (2016). Metodologi pengajaran. Jakarta: Bumi Aksara.

Mujtahidin. (2011). Pengembangan Profesi Guru. Malang: UIN Maliki Press.

Mulyasa. (2013). Pengembangan Dan Implementasi Pemikiran Kurikulum. Bandung: Rosdayakarya.

Nasution, M. T. (2010). Penuntun Membuat Tesis dan Skripsi disertai Makalah. Bekasi: Bumi Aksara.

Purwanto, Ngalim. (2014). Ilmu Pendidikan Teoritis dan Praktis. Bandung: PT Remaja Rosdakarya.

Rusman. (2014). Model-Model Pembelajaran. Jakarta: Rajawali Pers.

Wardani, K. (2010, November). Peran guru dalam pendidikan karakter menurut konsep pendidikan Ki Hadjar Dewantara. In Proceeding of The 4th International Conference on Teacher Education; Join Conference UPI \&UPSI (pp. 8-10).

Yusuf, S. \& Sugandhi, N. M. (2011). Perkembangan Peserta Didik. Jakarta: PT Raja Grafindo Persada.

Zubaedi, Z. (2013). Pengembangan Masyarakat Wacana dan Praktek. Jakarta: Pustaka Kencana. 
Habibah \& Putri

Reseacrh and Development Journal of Education, 7(2), 343-352

Zuchdi, D. (2008). Menentukan Kembali Pendidikan yang Manusiawi. Jakarta: Pustaka Nasional RI. 